Олександр Вдовін, Національний університет оборони України імені Івана Черняховського, м. Київ ORCID ID: 0000-0002-5079-9207

Микола Паламар, Національний університет оборони України імені Івана Черняховського, м. Київ

ORCID ID: 0000-0003-2887-2110

DOI: $10.33099 / 2617-1775 / 2020-02 / 39-48$

\title{
ДОЦІЛЬНІСТЬ ТА ОСОБЛИВОСТІ ВПРОВАДЖЕННЯ АВТОМАТИЗОВАНОГО КОНТРОЛЮ РІВНЯ ІНДИВІДУАЛЬНОї ПІДГОТОВКИ ОФІЦЕРІВ У ВИЩОМУ ВІЙСЬКОВОМУ НАВЧАЛЬНОМУ ЗАКЛАДІ
}

У статті проаналізовано впровадження ефективних засобів контролю рівня навчальних досягнень в умовах дистанційного навчання та ефективність сучасної системи контролю рівня навчальних досягнень слухачів у закладах військової освіти Украӥни. 3'ясовано, щу недостатній рівень індивідуальної підготовки у військових частинах впливає на професійну підготовку офіцерів постійного складу вищих військових навчальних закладів (ВВНЗ). Внаслідок масової перепідготовки і підготовки максимальної кількості фахівців 3 використанням мінімальних коштів набирає актуальності в державі дистаниійна освіта. Відповідно виникає необхідність об'єктивної очінки результатів навчання, а саме ідентифікації, кількісної оцінювання та вимірювання сукупності знань, умінь, навичок, інших компетентностей, набутих особою у процесі навчання за певною програмою індивідуальної підготовки в умовах використання технологій дистаниійного навчання. Визначено доцільність формування ефективної стратегії управління прочесом індивідуальної підготовки у ВВНЗ, у тому числі в умовах дистанційного навчання, шляхом об'єктивної оцінки знань та впровадження рейтингу їх успішності з дисииплін.

Ключові слова: дистанційне навчання; індивідуальна підготовка у вищих військових навчальних закладах; автоматизований контроль рівня навчальних досягнень (АКРНД); засоби забезпечення індивідуальної підготовки офіцерів.

Постановка проблеми. Підвищення якості вищої освіти в Україні наразі одна 3 найактуальніших проблем, бо саме високий професіоналізм молодих спеціалістів, у тому числі і військових фахівців, $є$ запорукою їх конкурентоспроможності в умовах європейської інтеграції і впровадження стандартів НАТО, що визначають стратегічні орієнтири нашої держави.

Професійна підготовка військовослужбовців у вищих військових навчальних закладах здійснюється в формі індивідуальної підготовки, яка $\epsilon$ водночас цілеспрямованим процесом і результатом оволодіння системою знань, умінь i навичок, професійних компетентностей, формування на їх основі професійного світогляду та мислення. Визначення рейтингу слухачів у системі індивідуальної підготовки, обов'язкового для кар'єрного зросту офіцера, можливо лише в умовах об'єктивного оцінювання знань. Розглядається можливість i доцільність найбільш об'єктивного, на наш погляд, автоматизованого оцінювання рівня знань. 
Аналіз останніх досліджень і публікацій. В дослідженнях і публікаціях останніх років розглядаються різні аспекти дистанційного навчання, але проблемні питання об’ єктивного контролю знань, які набуваються дистанційно, більш за все пропонується вирішувати очно. Також багато науковців досліджують i проблему вдосконалення системи підготовки i створення автоматизованих систем контролю рівня навчальних досягнень у ВВНЗ.

Учений В. Кремень переконаний, що дистанційна форма освіти - реакція на зовнішні зміни, які відбуваються у світі (об'єктивні тенденції глобалізації світу, підвищення динаміки його соціально-економічного розвитку, бурхливий розвиток інформаційних і телекомунікаційних технологій). Контрольні заходи 3 навчальної дисципліни (предмета) при здійсненні підготовки фахівців за дистанційною формою навчання у навчальних закладах мають включати проміжний (тематичний, модульний), підсумковий та інші контролі знань, умінь та навичок, набутих слухачем у процесі навчання.

Усі контрольні заходи можуть здійснюватись відповідно до рішення навчального закладу дистанційно з використанням можливостей інформаційнокомунікаційних технологій, зокрема відеоконференц-зв'язку за умови забезпечення аутентифікації того, хто навчається, або очно.

На думку вчених Буяло О.В., Хамула С.В., Шкребеля Т.Г. важливою особливістю дистанційного навчання $€$ наявність у слухача здатності до самоосвіти і вищої, ніж при очній формі навчання, мотивації до навчання, тому компенсувати недостатню мотивацію слухача суворим систематичним контролем з боку викладача, на їх погляд, не завжди доцільно. Але вони вважають, що на основі результатів автоматизованого контролю рівня навчальних досягнень слухачів можна формувати ефективну стратегію управління освітнім процесом у ВВНЗ, у тому числі в умовах дистанційного навчання.

Науковці Державної прикордонної служби технології дистанційного навчання розподіляють на педагогічні та інформаційні технології та надають перевагу в організації контролю педагогічним технологіям дистанційного навчання.

Учений Свген Николаєв вважає, що освіта належить до стресових видів людської діяльності. Підготовка до дистанційних занять вимагає суттєво більших зусиль викладача, аніж традиційні способи освіти. Слухачі і викладачі у такій ситуації проводитимуть багато часу перед комп’ютером, що не є легким дозвіллям. Тому треба користуватись правилом - краще менше, та краще. Навчальний матеріал потрібно скорочувати. Зосередитись потрібно на ключовому, центральному в курсі та глибоко опрацювати це вужче коло питань. Відповідно, варто скоротити обсяг матеріалу, що виноситься на підсумковий контроль чи іспит. На слід давати такі “дистанційні” завдання: підготовка реферату, конспектування підручника, або іншого джерела, завдання, за підсумками виконання яких немає можливості надати змістовний зворотний зв'язок і взагалі, не варто давати надмірну кількість завдань. 
Мета статті: дослідження і обгрунтування доцільності застосування дистанційного навчання у системі індивідуальної підготовки офіцерів у вищому військовому навчальному закладі та можливостей найбільш об'єктивного оцінювання отриманих ними знань та вмінь.

Під час впровадження технологій дистанційного навчання індивідуальної підготовки офіцерів доцільно звернути увагу на два обов'язкових компоненти: індивідуальну роботу, що передбачає використання різних форм навчальних матеріалів i засобів дистанційного навчання (програмно-комп'ютерних продуктів, аудіо-, відеозаписів тощо), і діалог з викладачем, консультантом, іншими слухачами 3 використанням інформаційно-телекомунікаційних технологій навчання. Такий підхід стосується планування індивідуальної підготовки офіцерів протягом служби на основі дистанційного навчання.

Важливим засобом забезпечення індивідуальної підготовки офіцерів на основі дистанційного навчання, як показують результати аналізу, є навчальнометодичні комплекси у вигляді електронних підручників. Це ключовий компонент дистанційного навчання, який дає змогу самостійно засвоювати матеріал і об'єднує в собі властивості підручника, довідника, задачника та практикуму. Під час навчання офіцери самостійно вивчають навчальні матеріали і складають тести самоконтролю за якістю засвоєння навчального матеріалу.

Оскільки в основу організації індивідуальної підготовки за дистанційною формою навчання покладено цілеспрямовану інтенсивну самостійну роботу офіцера 3 вивчення навчальних матеріалів 3 мінімальним відривом від виконання службових обов'язків у зручний час, комплексні тестування за перше та друге півріччя (підсумкове тестування) проводять за всіма розділами вивченого матеріалу у строки, визначені планом-графіком вивчення тематики індивідуальної підготовки за дистанційною формою навчання.

Перспективи розвитку дистанційного навчання офіцерів у системі індивідуальної підготовки безмежні, тому виникає потреба у розширенні варіантів їх використання в освітньому процесі, розробленні спеціальних програм дистанційного навчання офіцерів у системі індивідуальної підготовки протягом служби.

Незважаючи на досить об'ємний перелік позитивних якостей дистанційної освіти, як і в будь-якій іншій формі навчання, в ній можна виділити кілька недоліків. Перш за все, це ускладнена ідентифікація дистанційних слухачів, оскільки на сучасному етапі розвитку технологій перевірити, хто ж саме складає іспит, досить складно. Крім того, досить вагомою проблемою $є$ низька пропускна спроможність електронної мережі під час навчальних чи екзаменаційних телеконференцій.

Для ефективного функціонування системи індивідуальної підготовки у ВВНЗ потрібно створювати умови, за яких показники, що впливають на якість індивідуальної підготовки, мають бути на достатньому рівні. Це забезпечується шляхом їх безперервного контролю, а в разі погіршення вчасного формування управлінського впливу - корегуванням. 
Контроль як перевірка результатів теоретичного і практичного засвоєння слухачем навчального матеріалу у дистанційному навчанні виправдав себе, і в першу чергу це тестовий контроль. Тести добре пристосовані для самоконтролю і дуже корисні для індивідуальних занять.

Системотехнічне забезпечення дистанційного навчання потребує включення таких пакетів тестових завдань для проведення контрольних заходів:

тестування із автоматизованою перевіркою результатів;

тестування із перевіркою викладачем.

Для автоматизованої перевірки результатів в умовах скорочення бюджету часу, відведеного для вивчення дисциплін, використовуються автоматизовані системи контролю рівня навчальних досягнень, що дає можливість не лише автоматизувати рутинні і трудомісткі функції контролю викладача, а й впровадити дієві гнучкі технології навчання залежно від рівня підготовки слухачів.

Автоматизований контроль рівня навчальних досягнень (АКРНД) може бути одним 3 інструментів контролю якості освіти взагалі у ВВНЗ. Використання сучасних комп'ютерних технологій у сфері вищої освіти дає можливість оптимізувати й автоматизувати механізми об'єктивного контролю рівня підготовки та уніфікувати всі форми контролю знань - вихідний, поточний, підсумковий та інші.

Впровадження АКРНД у системі індивідуальної підготовки офіцерів дає змогу максимально ефективно використовувати навчальний час заняття, контролювати знання слухачів в умовах обмеженого часу. У системі АКРНД слухач може відразу побачити свій результат, а викладач - констатувати рівень підготовки слухача виключно за об'єктивними даними і надалі звертати увагу на проблемні питання теми, коригувати відповіді слухачів, поглиблювати знання з конкретної теми.

Всі тестові завдання умовно можна поділити на дві групи:

- тести з вибраними відповідями;

- тести, які не містять еталонів (варіантів) відповідей.

До першої групи належать:

тести пізнавання - завдання, що передбачають надання альтернативної відповіді (“згоден” або “не згоден”, “так” чи “ні” тощо);

тести розрізнення - завдання, що містять варіанти відповідей, із яких треба вибрати одну або кілька;

тести співвідношення - завдання, у яких пропонують знайти загальне (схоже) або відмінне в об'єктах, зіставляти за властивостями, параметрами, класами тощо;

тести-задачі - завдання, у яких слухачу дають потрібні дані, умови виконання та варіанти відповідей, 3 яких потрібно вибрати правильну послідовність дій та операцій або визначити залежність якихось чинників.

Такі тести найкраще застосовувати для поточного контролю або самоконтролю у системі індивідуальної підготовки офіцерів. 
До другої групи належать тести-підстановки та конструктивні тести, які доцільно використовувати при здійсненні контролю під час вивчення багаточасових дисциплін.

Тести під час поточного та підсумкового контролю доцільно комбінувати 3 різних типів. Обсяг тестових питань - це прерогатива самого викладача. Однак, чим більше питань для самоперевірки заплановано, тим більшою буде ймовірність забезпечення відповідного рівня якості засвоєння знань. Важливим $\epsilon$ те, що для підсумкового контролю слід застосовувати окремо розроблені тестові завдання, які будуть відрізняться від використовуваних на інших етапах контролю і перевірки знань за безпосередньою участю викладача.

Щоб запобігти списуванню, слід складати тести так, щоб у них не було прямих асоціацій з текстом, наданим у мультимедійному чи іншому навчальному джерелі. Під час дистанційного навчання АКРНД може бути проведений у ході безпосереднього контакту викладача зі слухачем онлайн (у синхронному режимі) або офлайн (в асинхронному режимі).

У разі застосовування АКРНД онлайн у попередньо обумовлений час слухач входить на контрольну сторінку курсу, де розміщено текст із короткою інструкцією, відповідає на питання, не виходячи з мережі в режимі реального часу. Оцінка може бути виставлена автоматично (якщо в тесті лише вибирають відповіді або відповідь може однозначно відповідати еталону) або викладачем, якщо в тесті є відкриті питання). Час надання відповідей слід обмежувати. Не надана вчасно відповідь на питання змінюється наступним питанням.

Офлайн АКРНД не “прив'язує” слухачів і викладачів до конкретного моменту часу. Тести в певний час з'являються на сайті, слухач виходить із мережі, відповідає на тест, а потім пересилає його результати за допомогою електронної пошти, месенджера або будь-яким іншим соціальним медіа. Наприклад, слухач входить на сайт курсу, вирішує тестові завдання i, натискуючи на відповідну кнопку, надсилає результати тесту. Час відповіді, як правило, теж обмежений: скажімо, потрібно надіслати відповідь через годину після отримання. Час отримання та відправлення тесту фіксує програмне забезпечення, тому тут не може бути непорозумінь. Часовий критерій під час надання відповідей на тести вважається дуже важливим, тому його слід чітко дотримуватися. Найближчим замінником, придатним для отримання та фіксування часу надходження відповідей на тестові завдання, може бути SMSповідомлення, час відправлення e-mail тощо, що також $є$ способом фіксації та зберігання отриманих відповідей, реєстрації часу їх надходження. У разі застосування такого виду тестування зростає ризик того, що слухач відповідатиме не самостійно або отримає зовнішню підказку правильної відповіді, тому у цьому разі потрібно використовувати методичні і виховні маніпулювання.

Для організації контролю рівня навчальних досягнень слухачів у формі самотестування в системі індивідуальної підготовки офіцерів з використанням технологій дистанційного навчання слухачів забезпечують спеціально розробленими навчальним електронними посібниками, матеріалами тощо. 
Контроль якості знань можливий за змішаною схемою, що передбачає i АКРНД, і вирішення практичних завдань. Його недоліками можна вважати лише обмежену варіативність використання варіантів та форм надання відповідей.

Впровадження у процес індивідуальної підготовки офіцерів 3 використанням технологій дистанційного навчання АКРНД дає можливість автоматизувати обробку результатів контролю знань, підвищувати оперативність контрольних заходів, полегшити аналіз засвоєння навчального матеріалу за результатами контролю, отримувати статистично достовірну картину індивідуального прогресу кожного слухача. Таким чином, АКРНД може стати одним з інструментів, який дасть можливість індивідуалізувати та інтенсифікувати процес вивчення навчального контенту в умовах дистанційного навчання. В той же час максимально ефективну організацію проведення контрольних заходів можна забезпечити у разі вмілого поєднання переваг дистанційної і традиційної форм навчання, наприклад дистанційного проведення поточного контролю і самостійної роботи за допомогою АКРНД та безпосереднього контакту слухачів 3 викладачем, під час проведення підсумкового контролю рівня навчальних досягнень за дисципліну.

Слухачі і викладачі у такій ситуації проводитимуть достатньо часу перед комп'ютером, що не є легким дозвіллям. Тому треба користуватись правилом краще менше, та краще. Навчальний матеріал потрібно скорочувати. Зосередитись потрібно на ключовому, центральному в курсі та глибоко опрацювати це вужче коло питань. Відповідно, варто скоротити обсяг матеріалу, що виноситься на підсумковий контроль чи іспит. Не слід давати такі “дистанційні”" завдання: підготовка реферату, конспектування підручника, або іншого джерела, завдання, за підсумками виконання яких немає можливості надати змістовний зворотний зв'язок і взагалі, не варто давати надмірну кількість завдань. Крім того слід уникати недостатньо конкретних, розмитих критеріїв оцінювання результатів навчання, це приводить до суб'єктивізму в оцінці виконаної роботи.

Для оцінювання завдань доцільно розробити детальні схеми, які мають включати:

- визначені критерії оцінки;

- опис різних рівнів відповідальності виконаного завдання кожному критерію. Опис має бути змістовним: не просто “високий”, “середній” чи "низький” рівень виконання, а чіткі, конкретні ознаки роботи слухача, що свідчить про кожен рівень ії відповідальності критерію;

- можливу бінарність критеріїв: наявність/відсутність у роботі певної ознаки або правильно/неправильно виконана певна частина завдання;

- бали за кожен рівень відповідності кожному критерію.

Схема оцінювання має бути зрозумілою для неспеціаліста, а головне для слухача. Крім того, відгуки слухачів на роботи одне одного i самооцінювання кожним власної роботи за наданими викладачем критеріями важливі складові одержаного ними зворотного зв'язку. 
Проблемою $\epsilon$ недооцінка можливостей дистанційного навчання викладачами старших вікових груп. Велика частина педагогів вважають дистанційну освіту, як, втім, і заочну форму навчання, неповноцінною, так як під час дистанційного складання тесту або іспиту неможливо відстежити дії слухача. Дуже складно об'єктивно дати оцінку знань людині, яка під час складання тесту або іспиту може використовувати інтернет, навчальні матеріали, допомогу третьої особи. Хоча ця проблема вирішується, наприклад, застосуванням веб-камери, вона є суттєвим гальмівним фактором.

Крім цього, важливою проблемою є небажання викладачів постійно відстежувати новітні технології дистанційного навчання з причини їх великого, а часто і надмірного навантаження.

Частково ці проблемні питання буде вирішено, якщо в університеті запровадити повноцінний електронний документообіг для документів, що створюють викладачі (зокрема, екзаменаційні відомості).

Ефективність контрольних заходів індивідуальної підготовки буде підвищено, якщо під час розроблення змісту навчання дотримуватись певної послідовності планування.

Найважливішим є етап аналізу, який передбачає аналіз цільової групи, діяльності фахівця, завдань, умінь, знань, на яких базується вміння, визначення завдань навчання.

На етапі проектування визначають послідовність змісту навчання, обирають методи навчання, обирають або створюють засоби навчання.

Розвиток передбачає розроблення плану занять, презентації курсу, вибір навчальних засобів, розроблення вправ, і головне - контроль знань та умінь, які забезпечують вимірювання результатів.

Етап виконання - це пілотне навчання для корегування розробленої програми.

Останній етап - це оцінювання якості результатів навчання слухачів.

Для вимірювання рівня виконання слухачем відповідного показника компетентності викладач може користуватись таким важливим інструментом як модифікована таксономія Блума. Вона передбачає багаторівневу оцінку i демонстрацію ролі викладача та слухача на відповідному рівні, визначає рівні тестових завдань і питань до навчального матеріалу. Крім того, знання поділяються на фактичні, концептуальні, процедурні та метазнання (останні демонструють вміння слухача навчатися).

Рівень 6 - створення - оцінка "А";

Рівень 5 - оцінювання - оцінка "В";

Рівень 4 - аналізування - оцінка "C";

Рівень 3 - застосування - оцінка " $D$ ";

Рівень 2 - усвідомлення - оцінка "E”;

Рівень 1 - пригадування - оцінка " $F$ ".

На рівні 1 викладач скеровує, розповідає, показує, перевіряє, записує, оцінює, а слухач відповідає, згадує, розпізнає, описує, перекладає, або просто $є$ пасивним учасником. 
На рівні 2 викладач демонструє, слухає, задає питання, порівнює, заставляє, перевіряє, а слухач пояснює, описує, з'ясовує, демонструє, є активним учасником.

На рівні 3 викладач показує, супроводжує, спостерігає, оцінює, організовує, задає питання, а слухач вирішує завдання, демонструє застосування знань, розраховує, збирає факти, комплектує, ілюструє, конструює, є активним учасником.

На рівні 4 викладач розслідує, супроводжує, оцінює, діє як джерело знань, запитує, організовує, розглядає дискретно i критично, а слухач обговорює, розкриває, аргументує, обмірковує, думає глибоко, проходить тестування, проходить перевірку, задає питання, підраховує, наводить довідки, запитує, є активним учасником.

На рівні 5 викладач роз'яснює, погоджується, припускає, супроводжує і скеровує, а слухач формує думку й оцінює, обговорює, порівнює, критикує, запевняє, доводить, оцінює можливості, вирішує, підтверджує, $є$ активним учасником.

На рівні 6 викладач супроводжує, сприяє, проявляє увагу, аналізує, оцінює, а слухач проектує, планує, формує, використовує ризики, видозмінює, створює, пропонує, є активним учасником.

Певні складнощі викликає необхідність дистанційно оцінювати компетентності, а саме здатність особи виконувати певний вид діяльності за допомогою здобутих знань, умінь, цінностей та інших особистих якостей. Як показує визначення, компетентностями $\epsilon$ переліки дій (показників компетентності), які опанував слухач i може їх продемонструвати, тому необхідно відповідно до результату навчання за кожною компетентністю складати перелік показників, а це окреме дослідження.

Для підвищення об'єктивності оцінки рівня індивідуальної підготовки слід уникати недостатньо конкретних, розмитих критеріїв оцінювання результатів навчання, це приводить до суб' єктивізму в оцінці виконаної роботи.

Висновки та перспективи подальших досліджень. Отже якість дистанційної освіти не поступається в ідеалі якості очної форми одержання освіти, а поліпшується за рахунок залучення кадрового (науково-педагогічного) складу найвищої кваліфікації і використання в освітньому процесі найкращих навчально-методичних видань та контролюючих тестів 3 дисциплін.

Під час впровадження дистанційного навчання у систему військової освіти (зокрема, у систему індивідуальної підготовки офіцерів у ВВНЗ), розроблення та впровадження об'єктивного контролю знань та вмінь військових фахівців позитивне вплине на усі компоненти освітнього процесу: мету, зміст, організаційні форми, методи і засоби навчання тощо, що призведе до зростання рівня професійної підготовки та якості освіти військових фахівців, надання доступу до додаткових інформаційних ресурсів, зростання професійної мобільності військових кадрів, формування єдиного освітнього простору в рамках безперервної ступеневої системи навчання військових фахівців “через все життя". 


\section{ЛІТЕРАТУРА}

1. Наказ Міністерства освіти і науки України від 25.04.2013 № 466 “Про затвердження Положення про дистанційне навчання".

2. Заболотний Антон. Використання технологій дистанційного навчання в організації роботи студентів денної форми навчання // Вища школа. - 2015. - № 4-5. - С. 60-64.

3. Буяло О.В., Хамула С.В., Шкребель Т.Г. Перспективи впровадження системи автоматизованого контролю рівня навчальних досягнень слухачів в умовах дистанційного навчання // Міжнародна науково-практична конференція НУОУ (збірник доповідей 2019). 2019. - C. 33-40.

4. Кухаренко В.М., Баркатов I.В., Тюрін В.О. Вимірювання результатів навчання у дистанційному курсі // Міжнародна науково-практична конференція НУОУ (збірник доповідей 2019). - 2019. - С. 98-106.

5. Мірошніченко В.І., Завідович В.В., Особливості професійної підготовки офіцерівприкордонників на основі дистанційного навчання // Міжнародна науково-практична конференція НУОУ (збірник доповідей 2019). - 2019. - С. 107-112.

6. Охрамович М.М., Мукогоренко О.С., Ряба Л.О. Дистанційна форма навчання в системі підготовки військових фахівців // Міжнародна науково-практична конференція НУОУ (збірник доповідей 2019). - 2019. - С. 145-149.

7. Николаєв Свген., Як підтримати чесність дистанційного навчання. // Освіта України. - № 18-19, 2020. - C. 10.

\section{REFERENCES}

1. Nakaz Ministerstva osvity i nauky Ukrainy vid 25.04.2013 № 466 “Pro zatverdzhennia Polozhennia pro dystantsiine navchannia".

2. Zabolotnyi Anton. Vykorystannia tekhnolohii dystantsiinoho navchannia $\mathrm{v}$ orhanizatsii roboty studentiv dennoi formy navchannia // Vyshcha shkola. - 2015. - № 4-5. - S. 60-64.

3. Buialo O.V., Khamula S.V., Shkrebel T.H. Perspektyvy vprovadzhennia systemy avtomatyzovanoho kontroliu rivnia navchalnykh dosiahnen slukhachiv v umovakh dystantsiinoho navchannia // Mizhnarodna naukovo-praktychna konferentsiia NUOU (zbirnyk dopovidei 2019). 2019. - S. 33-40.

4. Kukharenko V.M., Barkatov I.V., Tiurin V.O. Vymiriuvannia rezultativ navchannia u dystantsiinomu kursi // Mizhnarodna naukovo-praktychna konferentsiia NUOU (zbirnyk dopovidei 2019). - 2019. - S. 98-106.

5. Miroshnichenko V.I., Zavidovych V.V., Osoblyvosti profesiinoi pidhotovky ofitserivprykordonnykiv na osnovi dystantsiinoho navchannia // Mizhnarodna naukovo-praktychna konferentsiia NUOU (zbirnyk dopovidei 2019). - 2019. - S. 107-112.

6. Okhramovych M.M., Mukohorenko O.S., Riaba L.O. Dystantsiina forma navchannia v systemi pidhotovky viiskovykh fakhivtsiv // Mizhnarodna naukovo-praktychna konferentsiia NUOU (zbirnyk dopovidei 2019). - 2019. - S. 145-149.

7. Nykolaiev Yevhen., Yak pidtrymaty chesnist dystantsiinoho navchannia. // Osvita Ukrainy. - № 18-19, 2020. - S. 10.

\section{PEЗЮME}

Александр Вдовин, Национальный университет обороны Украины имени Ивана Черняховского

Николай Паламар,

Национальный университет обороны Украины имени Ивана Черняховского

Целесообразность и особенности внедрения автоматизированного контроля уровня индивидуальной подготовки офицеров в высшем военном учебном заведении

В статье проанализированы внедрения эффективных средств контроля уровня учебных достижений в условиях дистанционного обучения и эффективность современной 
системы контроля уровня знаний слушателей в учреждениях военного образования Украины. Выяснено, что недостаточный уровень индивидуальной подготовки в воинских частях влияет на профессиональную подготовку офицеров постоянного состава высших военных учебных заведений. Вследствие массовой переподготовки и подготовки максимального количества специалистов с использованием минимальных средств приобретает актуальность в государстве дистанциионное образование. Соответственно возникает необходимость объективной оценки результатов обучения, а именно идентификации, количественной оценки и измерения совокупности знаний, умений, навыков, других компетенций, приобретенных лицом в прочессе обучения по определенной программе индивидуальной подготовки в условиях использования технологий дистанционного обучения. Определена целесообразность формирования эффективной стратегии управления прочессом индивидуальной подготовки в ВУЗа, в том числе в условиях дистаниионного обучения, путем объективной оценки знаний и внедрения рейтинга их успеваемости по дисииплинам.

Ключевые слова: дистанционное обучение; индивидуальная подготовка в высших военных учебных заведениях; автоматизированный контроль уровня учебных достижений (АКРНД); средства обеспечения индивидуальной подготовки офицеров.

\title{
SUMMARY
}

\author{
Oleksandr Vdovin, \\ National University of Defence of Ukraine \\ named after Ivan Chernyakhovskyi \\ Mykola Palamar, \\ National University of Defence of Ukraine \\ named after Ivan Chernyakhovskyi
}

\section{Expenditure and features of implementation of automated control of the level of individual training of officers in the higher military committee}

The introduction of effective means of the educational achievements level control in the distance learning environment and the efficiency of the modern system of the students educational achievements level control in the military education institutions of Ukraine are analyzed. It was found that the insufficient level of individual training in the military units affects the professional training of officers of the permanent staff of higher military educational institutions (HMEIs). Accordingly, there is a need for an objective assessment of learning outcomes, namely the identification, quantification and measurement of knowledge, skills, abilities and other competencies acquired by a person in the process of learning a certain program of individual training using the distance learning technologies. The suitability of forming of an effective strategy for managing the process of individual training in higher education, including in the distance learning environment, by objective assessment of the knowledge and the introduction of a rating of the success in disciplines.

Key words: distance learning; individual training in higher military educational institutions; automated control of the educational achievements level; means of providing individual training of officers. 